\title{
The Role of Bioeconomy in the Future Energy Scenario: A State-of-the-Art Review
}

\author{
Martina Perišić ${ }^{1}\left(\mathbb{D}\right.$, Ernest Barceló ${ }^{2,3}$, Katarina Dimic-Misic ${ }^{2}$, Monireh Imani ${ }^{2}$ and Vesna Spasojević Brkić ${ }^{1, * \mathbb{C}}$ \\ 1 University of Belgrade, Faculty of Mechanical Engineering, Kraljice Marije 16, 11000 Belgrade, Serbia; \\ mperisic@mas.bg.ac.rs \\ 2 Department of Bioproducts and Biosystems, School of Chemical Engineering, Aalto University, \\ 00076 Helsinki, Finland; ernest.barcelo@omya.com (E.B.); katarina.dimic.misic@aalto.fi (K.D.-M.); \\ monir.imani@aalto.fi (M.I.) \\ 3 Omya International AG, Baslerstrasse 42, 4665 Oftringen, Switzerland \\ * Correspondence: vspasojevic@mas.bg.ac.rs
}

Citation: Perišić, M.; Barceló, E.; Dimic-Misic, K.; Imani, M.; Spasojević Brkić, V. The Role of Bioeconomy in the Future Energy

Scenario: A State-of-the-Art Review. Sustainability 2022, 14, 560. https:/ doi.org/10.3390/su14010560

Academic Editors: Matevz Obrecht and Tomislav Rožić

Received: 5 December 2021

Accepted: 23 December 2021

Published: 5 January 2022

Publisher's Note: MDPI stays neutral with regard to jurisdictional claims in published maps and institutional affiliations.

Copyright: (C) 2022 by the authors. Licensee MDPI, Basel, Switzerland. This article is an open access article distributed under the terms and conditions of the Creative Commons Attribution (CC BY) license (https:// creativecommons.org/licenses/by/ $4.0 /)$.

\begin{abstract}
The bioeconomy aims at decreasing reliance on fossil fuels, preventing or reducing climate change, eliminating insecurity, and efficiently using resources; however, fierce controversy exists on conceivable pathways to accomplish these objectives. The transport sector alone, which encompasses all other industrial sectors, has grown with regard to its energy demand by $50 \%$ over the past 30 years. The aim of this paper is to promote a dialogue as to whether an economy based on biomass can be more sustainable than today's existing economies, considering that the economy needs to expand and be boosted, while creating a cascading and recycling system. This semi-systematic review paper discusses four research questions based on findings from the last 20 years: (i) What are the crucial issues in the ongoing debate on the development of a sustainable bioeconomy concept? (ii) Where are the major conflicting points and focuses? (iii) How does the bioeconomy follow current urbanization and land-abandonment trends? (iv) How will the crisis linked to the COVID-19 pandemic change these previous scenarios? As it is not easy to currently predict which pathway will be the most effective, whether it be the one taken as of now or a specific novel pathway, this article recommends following a strategy that is diverse regarding its approaches to shaping the bioeconomy and further funding of renewable energy sources, along with the involvement of urban planning. In addition, conclusions are validated through a questionnaire completed by 51 experts in the field.
\end{abstract}

Keywords: sustainable bioeconomy; renewable energy; global changes; industrial sectors; transportation

\section{Introduction}

In the last two decades, the carbon intensity of the power industry has not significantly declined $[1,2]$. Recently, the rapid development of sustainable power sources, together with the reduction of the share of electricity produced by coal, has actually encouraged a continuous increase in the carbon intensity of the power sector [2]. In spite of rapid gains in sustainable power sources, the growth in energy demand has caused an increase in total carbon emissions from the power sector [3]. In short, decarbonization in the power sector has not been carried out quickly enough [4]. To preserve the level of carbon emissions from the electricity sector at the 2015 level, renewable generation needed to grow more than twice as quickly as it actually did [5].

Starting with energy consumption, the bioeconomy as a global social movement has the aim of building a platform for the mitigation of climate change through huge investments in research, education, and technology towards the promotion and development of renewable energies, mainly from biomass $[6,7]$.

Biomass refers to the use of organic material to generate energy, while bioenergy is produced from organic matter and is emerging as one of the major renewable energy sources. Both living plants (wood, algae, and crops) and waste from the food and forest 
industries can be used as such or processed in biorefineries into ethanol, biodiesel, and methane gas to create heat via combustion.

In the contemporary bioeconomy, biomass from the agricultural and forestry sectors is considered to be the most abundant, and therefore essential, raw material [1]. However, the use of animal products in the production processes is mentioned only marginally, mainly due to an analysis of the negative environmental effects of a meat-dominated nutrition, which is difficult to integrate into a bioeconomy model [8].

While it is widely agreed that the aims of the bioeconomy as a societal and economic movement are to reduce the reliance on fossil fuels while mitigating climate change and enabling secure food chains, there is no consensus on how to achieve these objectives in a sustainable way [8-10]. The original meaning of 'bioeconomy', defined in 1971, proposes an economic model in which natural resources and limits fit into a sound framework, has since undergone major changes $[11,12]$ in which the understanding of the phrase "of the economy" has been significantly improved. There are critics, however, with respect to the present-day bioeconomy as the "economization of ecology", the "neo-liberalization of nature", or the existence of "bio-capitalism". It was also always difficult to find a common vocabulary to address and discuss the various interpretations of sustainability due to the different academic backgrounds and professional experience of stakeholders, executives, and activists involved in the processes that developed the bioeconomy [13].

Transdisciplinary research [14] has been utilized as one of the possible means to integrate the various industrial sectors that are involved in the development of bio-based products. Accordingly, it is not surprising that there are numerous open research questions around the present concept of the bioeconomy, and numerous possible routes to the development of a sustainable bio-based economy. An analysis of the bioeconomy's structure can lead to a better understanding of what message it has delivered in the past and what it is offering in the present and future. A special emphasis should be placed on its activities regarding the expansion of various industrial sectors such as agriculture, forestry, chemicals, and food, along with the transportation sector that envelops all of these, as well as upcoming opportunities and risks. Energy scenarios are very important pillars for the development of policy goals by evaluating a broad range of future options, but the role of the bioeconomy in future energy scenarios is still not sufficiently clear.

This paper contains an extensive semi-systematic review of the literature aimed at uncovering the role of the bioeconomy in future energy scenarios and at filling the apparent research gaps. It also adds an empirical survey and experts' opinions to confirm the conclusions drawn on the basis of this state-of-the-art review. Accordingly, the contribution of this paper is twofold. First, it offers a comprehensive overview of the available literature in one report, and, second, conclusions drawn are confirmed by an empirical survey conducted on a sample of 51 respondents.

\section{State-of-the-Art Review Methodology}

This paper focuses on the current state of knowledge and is aimed to set priorities for future strategy, investigation, and research based upon of the literature of the last 20 years.

First of all, the research questions were clearly stated, including the following: (i) What are the crucial issues in the ongoing debate on the development of the sustainable bioeconomy concept? (ii) Where are the major conflicting points and focuses? (iii) How does the bioeconomy follow current urbanization and land-abandonment trends? (iv) How will the crisis related to the COVID-19 pandemic change previous scenarios?

A semi-structured review methodology was applied and the literature selection used the Preferred Reporting Items for Systematic Reviews and Meta-analyses (PRISMA) checklist. All sources of literature used are written in English and published in a peer-reviewed form. Geographical distribution is not limited, while the date of publication is limited to the last 20 years. We chose the period of 20 years due to the facts given in previous research [15], where it is shown that our society has become more aware of the climate emergency that challenges the future of the planet in the last two decades. The literature 
search was conducted from February 2020 to February 2021 using the Scopus, Google Scholar, and Web of Science databases. The search terms were obtained from the proposed research questions. They had to be explicitly mentioned in the title, abstract, or keywords of the examined articles in order to be included. This state-of-the-art review is structured so that Sections 2 and 3 discuss the background for the development of bioeconomy and the effect it has on various industrial sectors, which leads to the conclusion that such concepts of using biomass as an energy resource can create complex societal challenges. Reflections on the recent pandemic that may be considered a consequence of forest cutting and more contact of humans and wildlife are discussed in Section 5, while the availability and management of biomass sources through the discussion of biofuels and biorefineries are discussed in Section 6. The discussion section follows as the seventh part of this paper. Finally, the main conclusions are given in Section 8 and are checked by an empirical survey in the form of analyzing results of the questionnaire answered by 51 experts in the field.

\section{Global Trends as a Background to Bioeconomy Development}

The very first type of economy known to humanity was the bioeconomy, being a means of using living things from nature as a raw material for food, goods, and trade. Currently, global climate change has led to an accelerated development of modern life sciences and biotechnology that have a final aim to understand biological processes and modify or engineer areas in such a way that nature itself becomes a factory that provides both raw materials and products. A bioeconomy uses research and innovations in the biological and technology sciences to create products and trade, while sustainably managing biodiversity and public benefits.

The bioeconomy began to be recognized as a knowledge-based concept due its promotion by the European Union (EU) in the 2000s [16]. For Europe alone, the concept of bioeconomy appears to be an exceptionally promising tool to achieve self-sufficiency in the supply of raw materials. However, since the biomass potentials in Europe are quite limited, ideas about shaping a sustainable bioeconomy are questionable. Additionally, the real impact of crisis response management, such as in the cases of banks over-lending (2008) and the COVID-19 pandemic (2020-2021), is very difficult to quantify [17-20]. On the other hand, the scale and direction of urbanization from agricultural land to cities and from low-income nations toward development, which are always directed by economic opportunities, need to be considered [6]. The main migrations happen from rural to urban zones, but there are also flows in other directions, such as from rural to rural, urban to rural, and urban to urban areas [1,3]. Living in urban areas creates the need for very strong service sectors, and also shifts industry to be near consumers; therefore, $65 \%$ of the world's economically active population works in these two sectors, creating $97 \%$ of the world's gross domestic product (GDP) $[1,3]$. The rural depopulation migratory pattern negatively impacts environmental, economic, and social planning in the bioeconomy [21]. It is also becoming impossible to forecast national economic performance indicators since changes vary intensively both between nations and within nations, and these performance indicators largely depend on urbanization trends and societal developments. In order to use a minimum amount of energy and enable the maximum use of biomass, the bioeconomy model is expected to overcome the traditional linear economy models and enable trough cascade principles through the reuse and recycling of waste within a circular economy. The application of circular economy principles to the bioeconomy could make a significant contribution to increasing the bioeconomy efficiency. Accordingly, the aim of this paper is to take a deeper look into the role of the bioeconomy in the context of a circular economy.

However, the sustainable nature of a bioeconomy with bio-based products attained by the recycling and reuse of waste on a global scale may be considered an "elite narrative", particularly considering that growing economies and consumption trends of rapidly developing nations such as India will create an enormous need for biomass before the primary waste from which that biomass is produced is even accumulated. 
Additionally, global trends in energy consumption should be taken into account. The energy demand grew by $2.9 \%$ in 2018 and by $0.9 \%$ in 2019 , with this growth being primarily driven by China, the United States (US), and India, which contribute two-thirds of this increase in energy demand [22-24]. In the US, energy consumption has increased by 3.5\%, which is almost evenly distributed across all fuel types, and is especially pronounced in the demand for natural gas $[4,23,25]$. The intensive growth in power demand adds to the complexity of decarbonizing the power sector, as illustrated in Figure 1. It is described in the Pareto chart, which reveals the division of the world between a "vital few" countries and the rest of the world. The use of energy by sector in 2019 is given in Figure 2, where it becomes evident that transport counts for the largest percent, while the transport and manufacturing sectors both exceed the mean value for energy use.

\section{8}

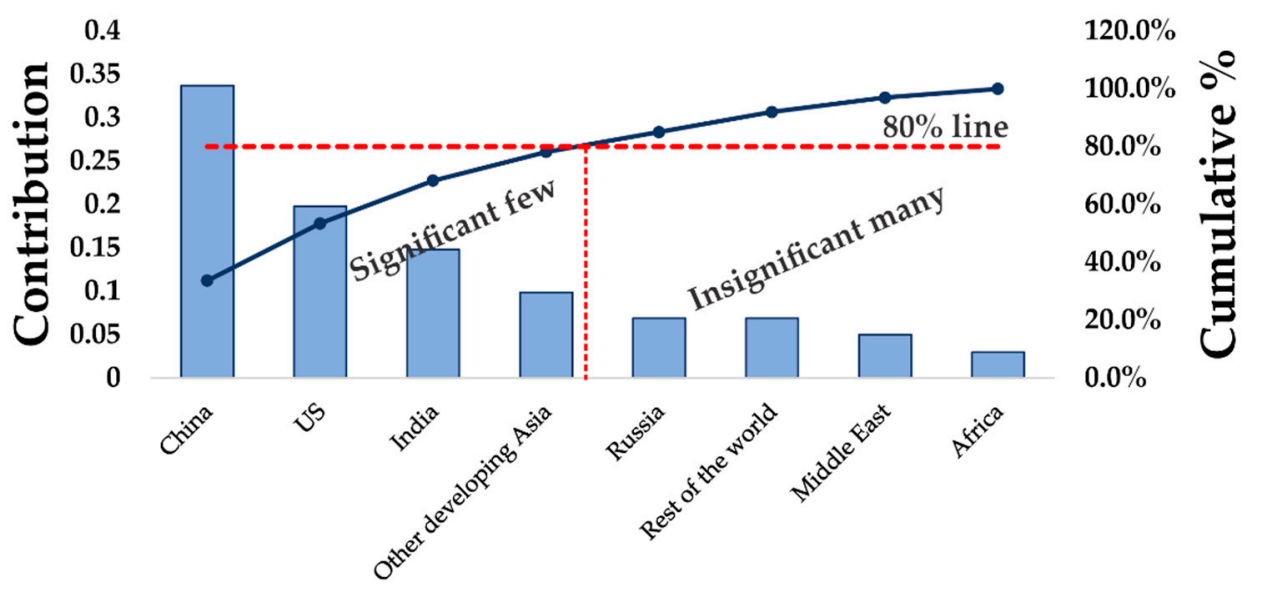

\section{Primary Energy Region}

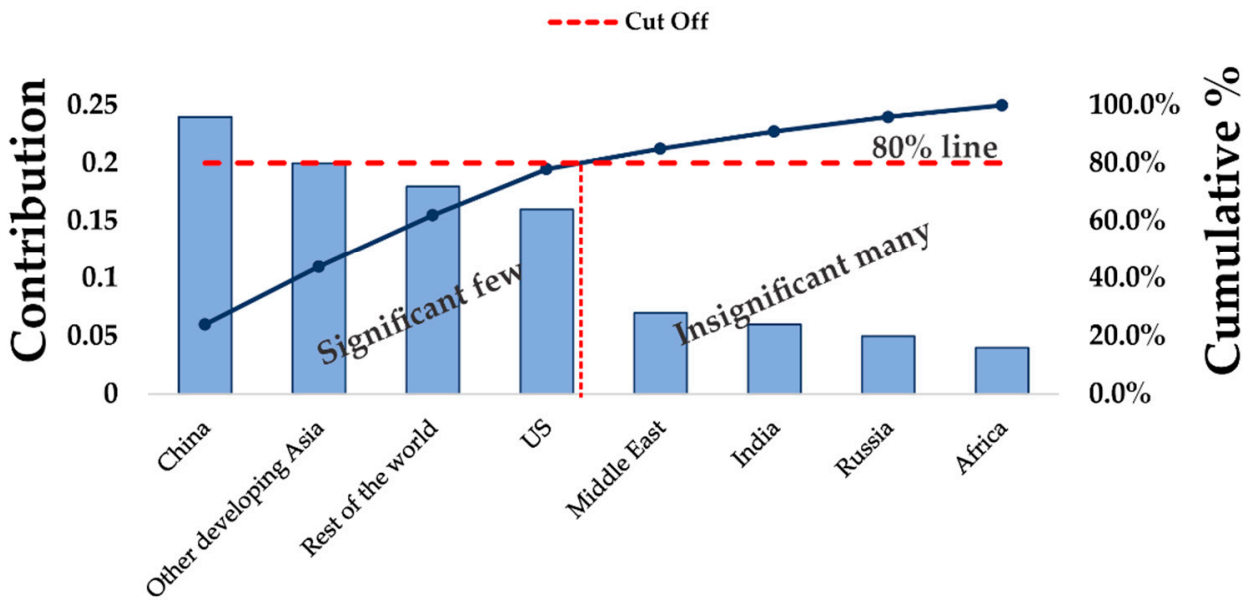

\section{Primary Energy Region}

$--\cdot$ Cut Off

Figure 1. Pareto chart of the contribution to primary energy growth in 2018 and 2019 (analysis is based on data given in $[4,22,23,25])$. 

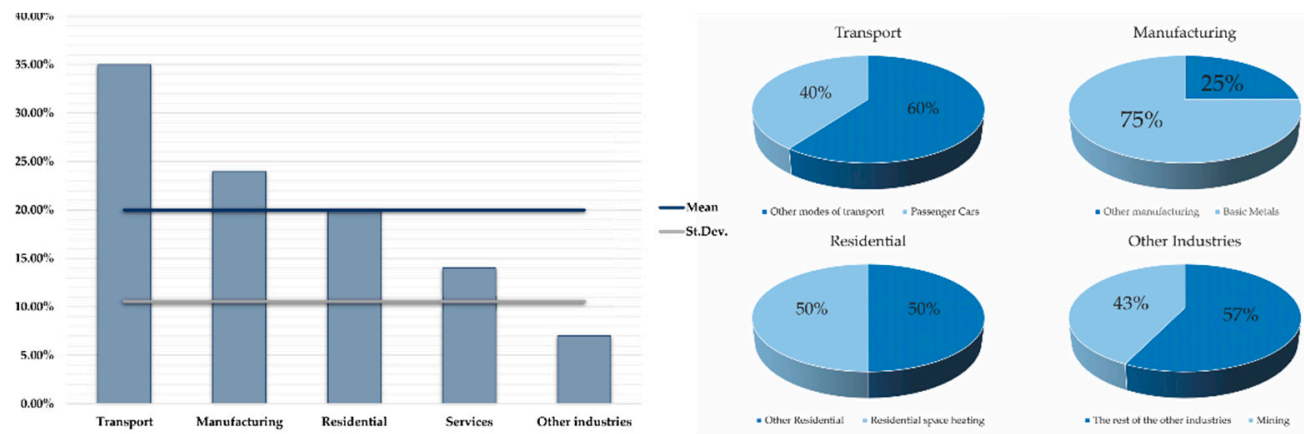

Figure 2. Use of energy by sector in 2019 (analysis is based on data given in [26]).

It is expected that the transition to a regime based on renewable resources will be filled with numerous obstacles. The goals, such as diminishing dependence on fossil fuels, reaching financial development and high economical gain, and mitigating climate change are not generally contentious, while hierarchical factors such as ensuring global food security, along with the increased consumption of biogenic resources, engender serious controversy and conflict of opinion over the possible pathways for achieving the more ambitious bioeconomy objectives. It is not possible to give a comprehensive descriptor for the bioeconomy as it is a very young multidimensional field, which is a mix of theories with a "learn-by-doing" approach as a reply to the urgent climate change problems.

Subsequently, the aim of this review is to consider the implications arising from related available literature, to identify main areas of disagreement in the discourse, and to parse trends by answering the following four research questions: (i) what are the crucial issues in the current polemics on profiling the bioeconomy; (ii) are there diverging views concerning these issues and where are the major points of conflict; (iii) how does the bioeconomy concept match, or not match, current urbanization and land-abandoning trends; and (iv) how will crises, such as those linked to pandemics, change previously accepted scenarios?

The fact that both the global population and urbanization are growing has led to an increase in carbon emission and climate change. The substitution of fossil fuels with diverse biogenic alternatives enables the mitigation of global warming and offers assistance for countries to meet their $\mathrm{CO}_{2}$ reduction plans. While there are distinctive sustainable choices for fulfilling future energy needs (for example wind-, sun-, or water-powered energy), biomass offers an extraordinary potential as a substitute for fossil fuels. It is also anticipated to improve the global seriousness of national industries and businesses, provide new workplaces, and contribute to a revival of rural parts of countries [5,27]. The review starts with background information regarding the development of the bioeconomy, with an aim to provide and discuss literature references and regulatory publications as well as governmental policies, which is followed by a determination of challenges, sustainability, and availability issues, as well as the agricultural and forestry aspects in the bioeconomy. Lastly, the discussion and conclusions are given.

\section{Emerging Green Economies}

The competitiveness between countries toward technological leadership is possible only through carefully planned networking between science, industry, and politics [8]. In recent decades, the adoption of regulations at different levels toward sustainable industry and carbon emission limitations has imposed challenges on maintaining modern economic targets of developing and developed economies using traditional fossil fuel power sources. The EU, the Organization for Economic Co-operation and Development (OECD), the Baltic Sea Region, the West Nordic countries such as Iceland, Greenland and the Faroe Islands, Australia, Finland, France, Germany, Japan, Malaysia, South Africa, Spain, Sweden, and the US already have defined their bioeconomy strategies [7]. The largest number of strategies was adopted between 2012 and 2014. 
The EU aimed to cut its carbon emissions by 2030 to levels that are $40 \%$ below the levels that existed 40 years ago through a strategy which consists of consumption reductions, higher energy efficiency, and the greater use of renewable energy and to become carbonneutral by 2050 [28]. In addition, for a sustainable use of biomass resources, its strategy brings the hierarchical utilization of biomass together with healthy food $[16,29,30]$ and satisfied societal needs [31]. The harvesting of wood biomass from forests should support development with an emphasis on increased employment in the bioeconomy sector, while smaller European countries should not be abandoned in improving the bioeconomy in favor of centralized producers and countries rich in forest resources [8,29,32]. A conversion from fossil-fuel-based energy to renewables is underway internationally and in the EU's bioeconomy [5,22]. The use of the EU bioeconomy as a trademark and an exchange characteristic of the European response to ecological issues was a procedure which started more than 30 years ago, advancing from an idea to financial and research funding actions, to the creation of bioeconomic policies and strategies $[30,32,33]$. A move toward a bioeconomy requires huge investments and increases business uncertainty, which is in contrast to the fact that it is the key driver for sustainable productivity growth. While all strategies thus far share the motivation to advance the bioeconomy, different countries have adapted varying priorities. It is well understood that smaller countries should not lag behind in favor of centralized producers and countries with huge forest resources. The North Rhine-Westphalia strategy was developed to contribute within the wellbeing segment due to its long tradition of involvement within the pharmaceutical industry [34,35], whereas the Canadian regions, which are rich in forest resources, focus on the forestry sector, while the West Nordic countries invest in forests and marine resources [36].

In Europe, where numerous enterprises are exceptionally reliant on fossil fuels and petroleum products, forest biomass is seen as the answer for the socially responsible and secure economic growth due to the steady fuel supply $[29,32,33,35]$. The innovative work in research and development in support of the bioeconomy is profoundly contributing to creative new advances, resulting in organizations delivering novel items and materials from bioresources, such as bioplastics and nanocellulose materials. The EU Renewable Energy Directive and the EU Fuel Quality Directive contain mandatory ecological sustainability criteria for the implementation of the bioeconomy through strategies that define rules for biomass feedstock conversion into biofuels [6,37-40]. Challenges are arising not only from the fact that it is difficult to fulfill the valuation of financial expectations from the bioeconomy concept, but also from the fact that if focusing industrial development on renewable energy sources, the growth should be more accelerated than theoretically feasible in order to reach carbon emissions that match the 2015 level.

Asia/Pacific is the area with the largest percent of adopted biofuel strategies (33\%), followed by Europe (31\%). Transnational strategies are the least represented, with only 9\% of total documents, as shown in Figure 3. Regarding Europe, it can be noted that the number of adopted strategies does not depend on GDP. Most of the European countries have adopted only one of the directives (Figure 4). 


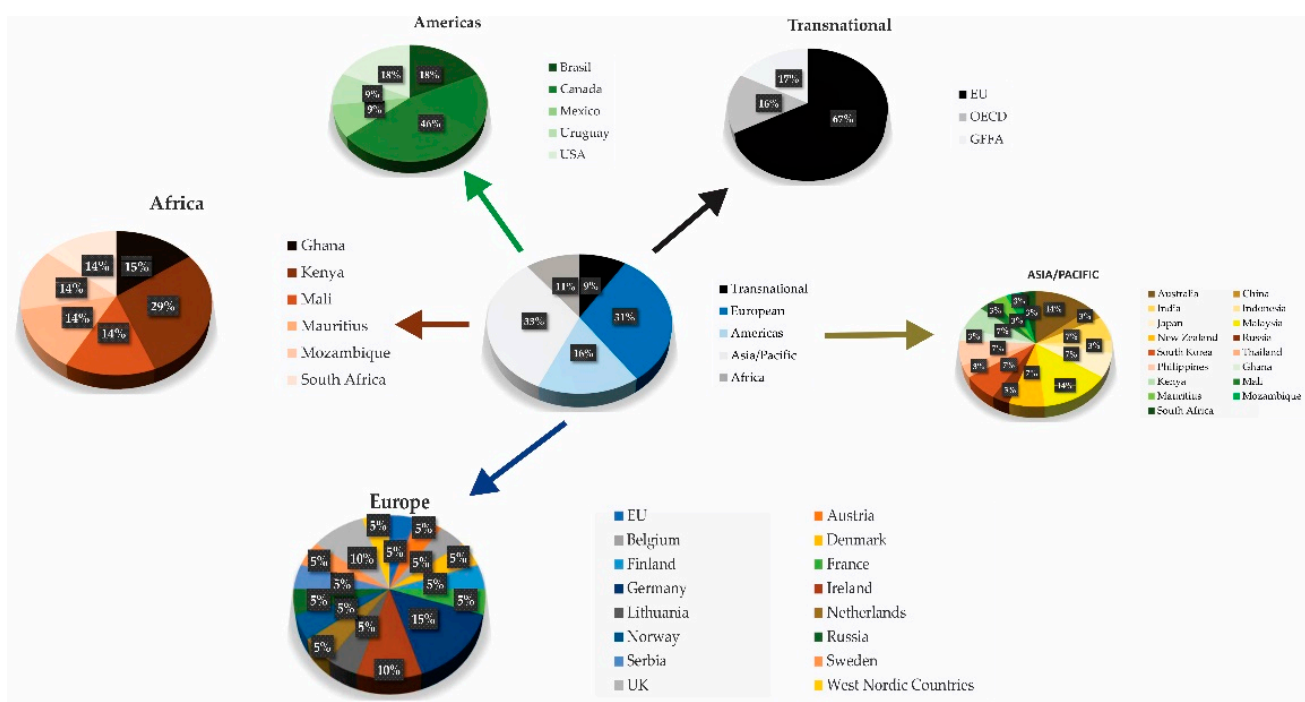

Figure 3. Distribution of adopted documents theworld (analysis is based on data given in [6,38-42]).

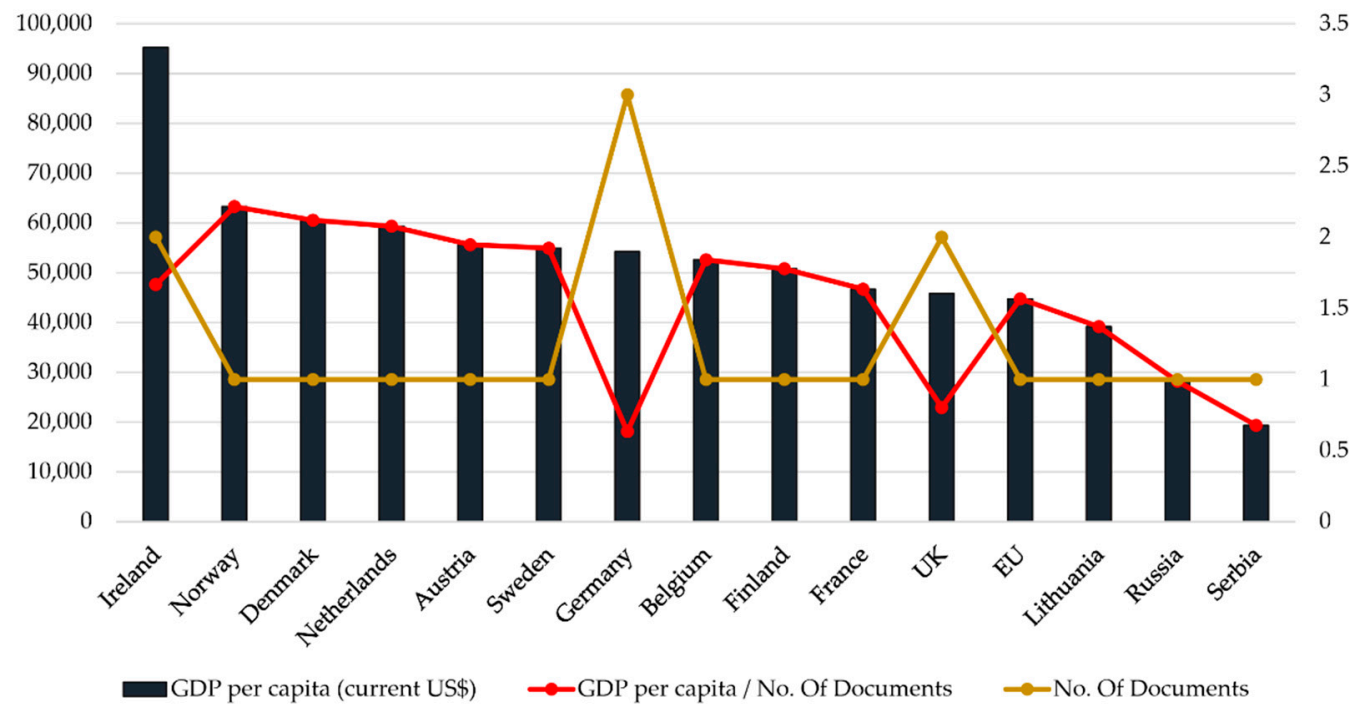

Figure 4. Relationship between adopted documents and GDP per capita in 2020 for European countries (analysis is based on data given in [6,38-41,43]).

Regulations in China, the US, India, and other developing Asian countries, which contribute vitally to primary energy growth, exist; however, there is no evidence of regulations in Russia, which also contributes significantly to primary energy growth. The EU and Germany have the largest number of documents in the field, and numerous monetary and research funding activities contributing to success in reaching bioeconomic targets [7,44].

\section{Challenges, Sustainability, and Availability Issues in the Bioeconomy}

To succeed with bioeconomy initiatives, the issue of land must be seriously approached. In Europe, the existing surface dedicated to forest and agricultural activities at present is enough to fulfill the demand, but the attempt to expand such territory will face regulatory restrictions, such as Natura 2000 that aims to protect a maximum number of natural areas $[1,39]$. The use of land will need to be balanced between residential areas, industrial areas, agricultural food related areas, agricultural bioeconomy related areas, roads, railways, harbors, and airports, as well as natural protected areas. In some places, this will add more tension between the stakeholders, and in others, it will simply not be possible. Digging the "green gold" for one nation can be a road to misery for another. 


\subsection{Societal Challenges}

The implementation of a bioeconomy depends on the public investments and change of consumption patterns, mainly for urban consumers, through socio-ecological strategies. After centuries of population movement following the industrial revolution from rural zones to cities, we will need to make sure that all new forest and agricultural activities have the needed workforce, especially in light of recent situations, such as the pandemic, that restrict movement $[6,21]$. Societal movements have settled in the urban areas and are largely concentrated within megalopolises, which contradicts the concept of bioeconomy raw material supply. It is possible to create scenarios similar to the situation with fossil fuels, where two sides could be separated: one privileged side, where the extraction of crude oil is performed in remote areas in a few countries or offshore, and the work is not particularly intensive on the workforce; and one less-privileged side, where the oil is transported to the refinery and value is added. However, there is a real need of knowledge to improve this refinery process $[8,45]$. Refineries are considered vital for all countries, but extraction is vital only for a few, which can create negative consequences on democracy [18,31].

Developing countries are beginning to realize that renewable energy sources, led by biofuels, give a chance for a new beginning of industrialization, which will later come with advantages in the form of novel technologies and systems, such as multiple feedstock bioreactors [46]. Due to their huge area, new industrial blocks based on the biofuel value chain are built around the plantations, processing, distillation, and downstream capture and recycling of byproducts at levels of efficiency hardly obtainable in the Northern regions. However, bioethanol, as the first generation of biofuel, allowed for developed countries to concentrate on technological developments, which then provided the possibilities for the Southern regions to reap the benefits of the request to set up new industrial clusters which produce and export biofuels due to the way it was obtained (made from biomass supplied from tropical crops) [35].

Environmental consciousness might only be achieved through changes in both the concepts of bioeconomy and consumption patterns. While all national policies are investing into the development of the bioeconomy, it is most likely that fully developed countries will provide the realized and economically feasible processing facilities with high automation, while the raw materials will be provided by developing countries, where the working force is less expensive and willing to work and live in rural environments [47,48]. The migration could be a transitional solution, and, as always, could also create some side effects on the origin and destination countries. However, in the same way that China is moving production to Africa to reduce costs, when African countries improve their living standards, migration will no longer be an option $[6,37,44]$. The basic economic criteria will prevail, so it will be very difficult for all countries with the initiatives listed in Figure 3 to succeed at the same level in the implementation of their bioeconomy strategies [49-52].

A potential successful scenario could be achieved if the generation of biofuel is truly decentralized and performed as close as possible to the final point of consumption.

\subsection{Sustainability in a Biofuel Economy}

Numerous authors welcome the use of renewable energy sources, but point out that all sustainable criteria must be met [53-55].

There are authors that argue for the necessity of governmental regulations to prioritize the use of the extremely productive soils in the food industry due to the rapidly increasing global population and higher demands for food [56]. There is also an impact on the bioeconomy as energy production sites, particularly those for the first-generation biofuels (from food crops including maize, rapeseed, canola, soybean, sugarcane, and sunflower), develop only in good soil, which leads to land use conflicts, the risk of expropriations/land grabs, and the frustrations of small farmers who see economical potential in growing biofuel crops. The recent development of the second-generation biofuel feedstock, which do not rely on sugar- or oil-rich crops and that are not dependent on soil quality, can help 
mediate the land use situation, but can still cause constraints regarding the accessibility of water for the growth of food crops.

Despite the fact that the purpose of a bioeconomy is clear, the term sustainability is interpreted in different ways and its rationales usually are not precisely defined. The recognized positions can be separated into three groups: (i) those that contend biomaterials and bioeconomy sustainable, due to the fact that biomass is renewable; (ii) those that contend that the bioeconomy will only add to sustainability if all aspects and perspectives of sustainability are met; and (iii) those that believe that favorable effects might be conceivable in the short run but will turn out to be negative and unpredictable in the case of urbanization and populace development patterns.

Previous trends are the basis for understanding the shift to European bioeconomy advancement, and its approach to a sustainable development model is criticized to be "weak" when nature is considered as a "resource" that must be continuously used.

One of the most serious objections to biomass use stems from the belief that the available biomass will be insufficient to meet the demand for food security and will create competition for land grabbing and land acquisition between food and energy crops $[6,51,57]$. The solution to this problem could be the second-generation biofuel crop, Miscanthus giganteus, by using non-food crops, but there are opinions that this will not solve land use conflicts. The definition of sustainable biomass, particularly with to biofuels, food crops and, land that can be used for other renewable energy sources such as solar and wind remains an open question [58,59].

Agricultural commodity prices and the cost of biomass production, land fertilization, pollution, and political instabilities in producer countries are included as key factors [60]. Certain researchers $[60,61]$ believe that the total biomass potential is sufficient to meet demand, using only lands that are not necessary for food production, while others have the opposite opinion [62] based on social, technological, and economic constrains.

Two types of biomass could be distinguished from its availability aspect for biofuel: (i) sustainably available waste (SAW) biomass; and (ii) dedicated fuel (DF) crops [35,63]. SAW does not require new land for cultivation, as it uses existing agricultural and forestry assets. Being sustainable, SAW biomass contains crop, residues, and waste, collected in an environmentally sound manner. The SAW biomass could be treated in the same way as other primary energy sources and can be used for electricity generation, $\mathrm{H}_{2}$ production, liquid fuel for transportation, or heat. As another option, DF crops are cultivated on land not used for the production of food crops, livestock feed, or forest products, and thus the land on which they are cultivated becomes biofuel land [64]. DF crops contain a mixture of crops that have up to $200 \%$ greater biomass yield than SAW biomass [32]. Although DF crops were initially proved successful, it is questionable if the sunlight used there would be more efficiently used when collected in another form, such as heat, electricity, or hydrogen $\left(\mathrm{H}_{2}\right)[21,65,66]$. Solar energy recovered as fuel energy (S2F) is a percentage of incident solar energy, whilst solar energy can also be recovered as mechanical energy (S2W) [67]. The efficiency of converting DF crops to liquid fuel should be higher than S2F efficiency, whilst S2W efficiency for DF crops is significantly worse than that for alternative routes of using solar electricity or $\mathrm{H}_{2}[48,68]$. Finally, in the context of policymakers, the concept of "green" and "sustainable" should be understood as compatible with the ecological resources of the planet, both regionally and nation-wide.

Finally, it is evident that an investment in alternative energy sources via the bioeconomy is a long-term process that each country can obtain with various tools through strategic investments. While generating economic benefits, sustainable development can be reached only if public interests are fulfilled and technologies and practices are transferred into assets in the competitive global market. Since the concept of bioeconomy as a set of diverse practices which are based on the development of products and commodities from renewable resources is not well understood, it is questionable if it will remain part of a political project and business model domain or if it will manage to become a transnational industrial and societal driving force for a sustainable future on the global scale. In our 
opinion, preventing the radical regularization that should be aligned with the initial idea of bioeconomy, and instead using a "layer-by layer" approach, will add more sustainable long-term benefits and prevent "neo-liberal-bio-capitalism".

\subsection{Crisis Response Management/Impact of COVID-19 and Bioeconomy}

The COVID-19 pandemic issues have caused numerous changes in social and economic behavior at the worldwide level. Due to COVID-19, planting and harvesting plans have not been executed in the desired way due to the lack of workers, which has caused unfinished harvesting of some fruits [69], as well as with evident disruption in the transportation, distribution, and other processes in supply chains. When the free movement of people is restricted (as with COVID-19) or when the conditions for migration are restricted (as in North America), it becomes extremely difficult to find workers ready to perform the needed tasks $[18,70]$. Societal and economic activities are slowed down, while environmental monitoring and climate services are challenged [71]. Previous work has anticipated the impact of the COVID-19 pandemic on GDP, energy consumption, and climate change, and expects a decrease of growth by $1.3 \%$ in 2020 and $1.32 \%$ in 2021 , and $1.25 \%$ in the next 4 years [72], while the average temperature is expected to be dropped by 0.05 and $0.02 \%$ in 2020 and 2021, respectively. The top 10 areas of the world where COVID-19 has been forecasted to have the greatest negative impact on GDP (both cumulative and amplified) are shown in Figures 5 and 6.

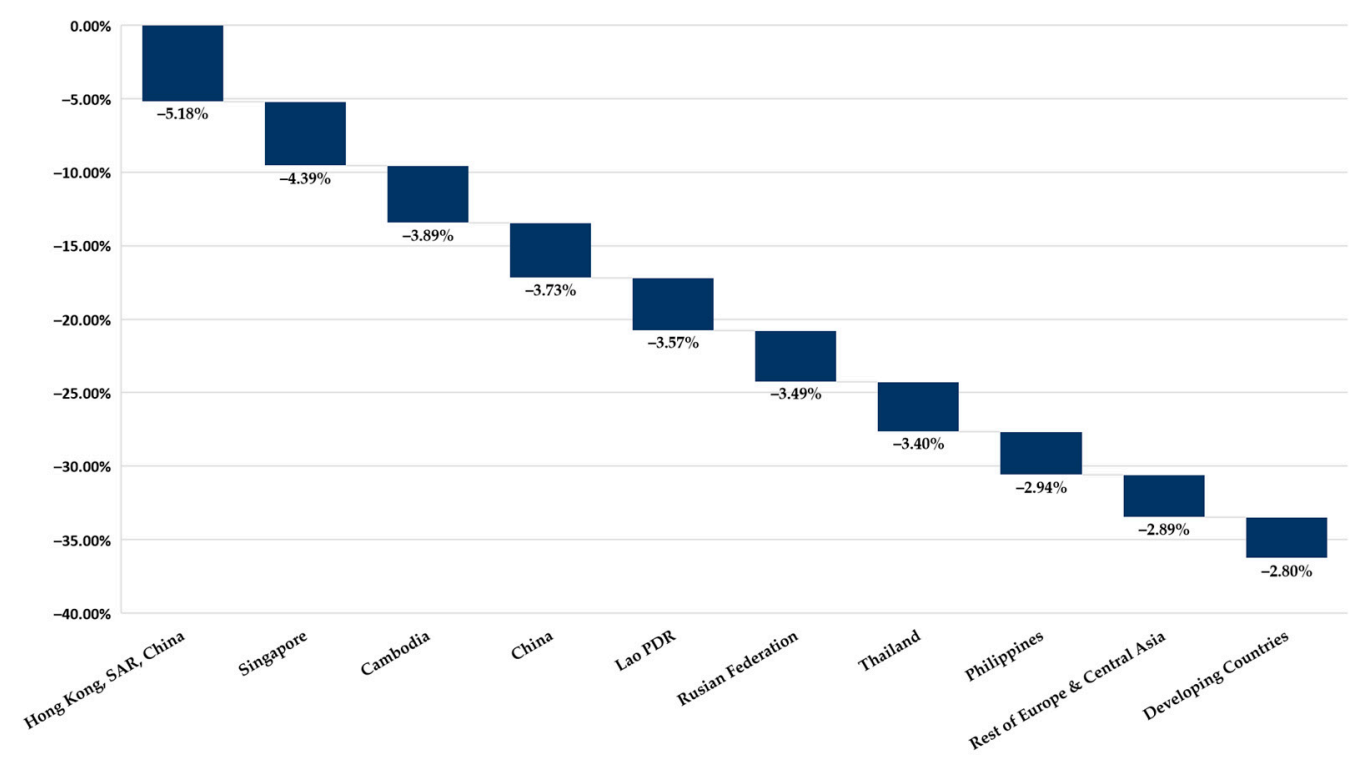

Figure 5. Cumulative COVID-19 consequences on global GDP for the top 10 areas of the world predicted to have the greatest negative impact (analysis is based on data given in [73]). 


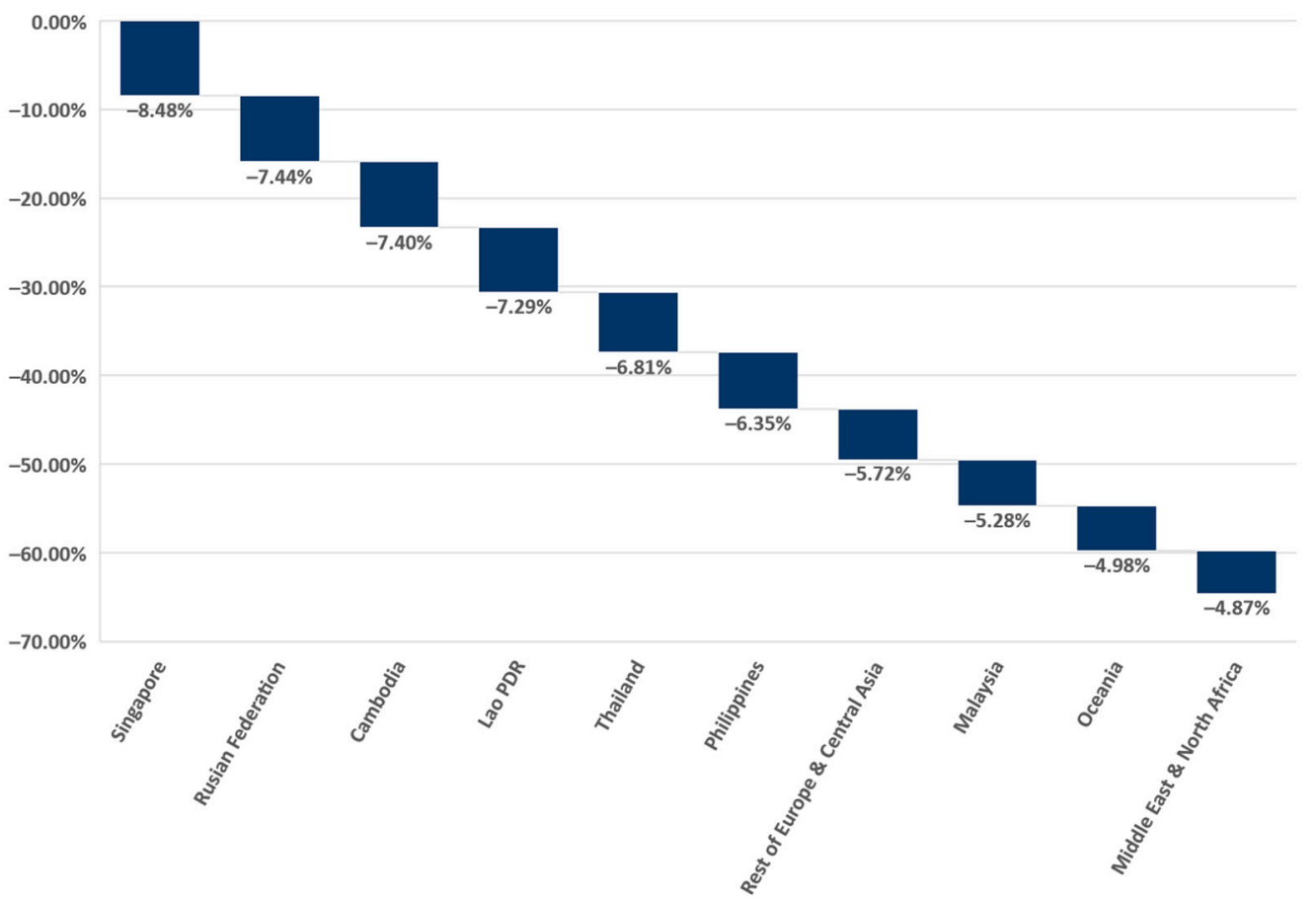

Figure 6. Amplified COVID-19 consequences on global GDP for the top 10 areas of the world predicted to have the greatest negative impact (analysis is based on data given in [73]).

The bioeconomy has a great potential to help in the recovery from the COVID-19 crisis. A socioeconomic prevention strategy for future epidemics aims to reduce pollution, which rationalizes the sustainable development and deindustrialization of polluting behavior for the production industry with huge costs and long-term benefits. The mitigation of pollution calls for the widest possible international cooperation; the pandemic crisis shows that climate changes are moving faster than strategies, illuminating the need for systemic changes. As such, it is also necessary to avoid the danger of slipping into a promissory societal revolution, unless there is a way to allow for a better understanding of the possibilities of its role in changing social practices, values, economic, and non-economic impact. More co-creation, openness, inclusiveness, and promptness are needed, while lower-level strategies need to address, in detail, all sustainability aspects, particularly the sustainable use of agricultural, forest, and marine resources.

\section{Production, Technology, and Economy of Biofuel Use}

\subsection{Different Models for Biorefineries and Centralization}

Due to its flexibility, road transport by trucks is used in bioenergy plants and it is especially suitable for facilities within a distance of less than $100 \mathrm{~km}$. For biomass to liquid fuel (BTL) plants, low-cost feedstock is favored as it gives lower production and transportation costs, which limits transportation to up to $100 \mathrm{~km}$ [38]. In addition, it is assumed that wood chips will be delivered by trucks. Due to the lack of truck drivers in developed countries, autonomous transport might be the solution, first for road transport, and later on for this new demand of drivers for primary biomass transport [5,47].

The easy implementation of wood biomass into biorefineries is expected because of existing biorefineries and the existing know-how on wood production, handling, and processing due to the practices developed in the pulp and paper manufacturing industries [48]. The biomass produced in the tropical regions could be imported into the US and Europe as a fuel $[6,44,52]$.

Environmental issues linked with the production of the first generation of biofuels in cases where poor countries need to produce the waste amounts of biomass for the needs of OECD countries, the issues of deforestation, genetically modified crops, species 
loss, water usage and runoff, herbicide and pesticide use, soil degradation, and land energetic are being mitigated with the second generation of biofuel production. The second generation of biofuel involves the production of ethanol by the biochemical breakdown of lignocellulose, as well as the production of biodiesel from a range of biomass processes, such as fast pyrolysis for biooil or gasification and the Fischer-Tropsch process for synthetic biodiesel [29,31,74].

The development of the second generation of biofuels will dramatically raise the biomass available for the production of fuel in both the North and South regions for developed and less-developed countries. The second generation of biofuels utilizes nonfood-based biomass, such as agricultural and communal waste consisting of lignocellulosic biomass, which presents a low value waste for numerous industries. Its economic production on a large scale has not yet been achieved due to technological issues that are largely focused on the chemistry and structural aspects such as inertness and rigidity properties.

There are an increasing number of power plants that work on co-firing combinations of biomass and fossil fuels. Commonly used as an addition to petroleum-based fuels, biofuels can contribute to a decrease in the emission of air pollution and can increase octane.

\subsection{Technological and Economical Gaps within Biofuels}

Economic growth represents a crucial factor in the increase of energy demand. There is an obvious gap in biofuel technology between the OECD countries and the developing countries that grow the biofuels. The success of Latin American countries, like Brazil, in growing and exporting cane-sourced ethanol, at prices and at levels that make biofuels economically competitive with fossil fuels, has far exceeded those obtained by the EU and the US. This success was followed by other developing tropical countries that now grow sugar cane and other starch-rich crops for ethanol production and a variety of oilseeds for biodiesel production. India and China are also in the race to find their pathways for independence from fossil fuels [2].

The world's GDP is projected to grow by 3\% between 2015 and 2040. The highest growth rates are projected in non-OECD regions, where, thanks to the combined GDP growth of 3.8\% per year, energy consumption will increase, while in OECD countries GDP growth rate will be $1.7 \%$ per year [22]. Trade and transport enable economic growth, and fossil fuels remain as the dominant source of transport energy. Most of the world's energy growth is expected to occur in non-OECD countries. Non-OECD Asia, including China and India, is projected to account for over $50 \%$ of the total growth in energy consumption in the world until 2040 [70,75], as is shown in Figure 7. In addition, by 2040, energy use in non-OECD Asia is expected to exceed the amount of energy use in the entire OECD [76]. In 2019 , natural gas conditioned the growth of energy consumption, contributing more than $40 \%$ to the total increase. In the last 30 years, the US consumption has increased the fastest. Carbon also increased by $3 \%$, which is the fastest growth in the last seven years [22].
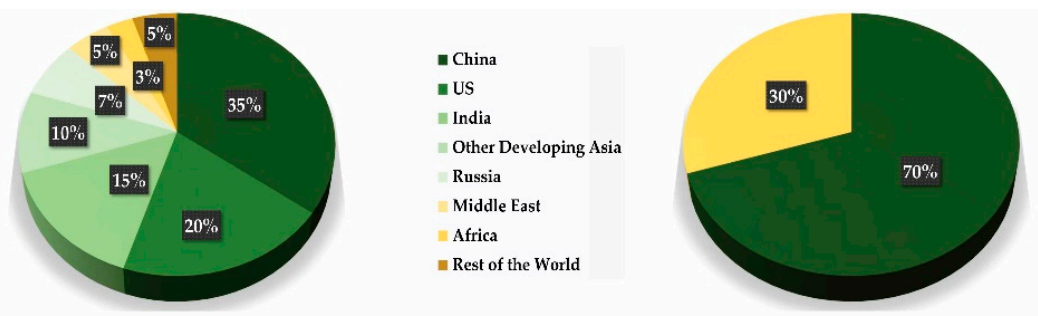
- China, US, India
$=$ Rest of the World

Figure 7. Global increase of world energy demand (analysis is based on data given in [22,23]).

For these reasons, there is a possibility that fossil fuels will not be able to be completely replaced by biogenic ones, especially if food production becomes a priority. Therefore, although there are some undiscovered possibilities in Asia, Africa, and South America, biomass remains as another scarce resource. 


\subsection{Liquid Fuels}

In order to compare yields of alternate processes for various biofuels, the biofuel produced per ton of biomass is converted to ethanol gallon equivalent (ege) units. The yield of 100 ege per ton of biomass is equivalent to the production of biofuel with an energy content of 8.014 MJ from a kilogram of biomass [52,77].

However, the carbon found in biomass is valuable because if it is released into the atmosphere during the conversion of biofuels, then collecting the same amount of carbon by growing DF crops would be energy inefficient. If, even after retreating all available biomass through augmented processes, there is still a need for liquid fuels, then the direct extraction of $\mathrm{CO}_{2}$ from the air and its conversion into synthetic fuel using solar energy and $\mathrm{H}_{2}$ is more efficient than growing DF crops.

In any case, the structure of a typical biomass is made up of cellulose, hemicellulose, and lignin $[1,29,78]$.

Unlike fossil fuels, biomass is characterized by a high atomic ratio of oxygen and carbon, which is from 0.4 to about 0.8 . This ratio depends on the source of the biomass, and results in an oxygen content of $40-45 \mathrm{wt} \%$ and lower energy content of lignocellulosic biomass [78].

The development of the biomass liquid fuel technology represents a future development for the energy industry [79]. Therefore, it is necessary to shift the focus towards biomass processing.

\section{Agricultural and Forestry Aspects}

Beginning in the 1960s, with the development of agriculture and the use of new technologies, there has been an increase in productivity worldwide. However, this progress also has negative aspects, the most significant of which were the loss of biodiversity, lack of fresh water, soil pollution, emissions of harmful gasses, and other similar environmental damage. It is assumed that global population growth by 2050 will lead to an increased demand for agricultural productivity $[38,80]$.

The sustainable intensification represents selective crop planning followed by an increase in yield per hectare, which will lead to minimizing the environmental damage and maintaining soil fertility. It is very likely that some regions will give up on increasing yields and unproductive agricultural land in favor of natural ecosystems. Certain experts suggest a strategy of sustainable intensification, which involves reducing yields from unsustainable land until a balance is established with the carrying capacity of agroecosystems [81,82]. The main streams in current agricultural development are precision farming, which leans largely on genetic engineering, and sustainable agro-ecological farming.

When it comes to forestry, it performs an important function by removing atmospheric carbon dioxide through photosynthesis. The net forest carbon sink is the balance between carbon input (photosynthesis) and carbon output. There are three main pathways of carbon output: respiration (50\%), decomposition (36\%), and carbon removal from the site through harvest, fire, run-off, and leaching (7\%) [83]. The terrestrial carbon uptake is increasing globally over recent decades [84]. Old forests have slower carbon storage than young forests, due to a decrease in growth rate, as old and dead trees are considered to be carbon pools with a low rate of carbon adsorption. The importance of carbon management towards the planned usage of carbon stocks in forests was addressed in the Paris Agreement document in 2015 at UNNFCCC COP21 [85].

With the development of technology, it is considered that the forest waste from other biomaterials will be used more widely for commercial bioenergy production [35]. The augmented use of forest biomass in energy consumption is firmly supported by forest policies at the EU level and within the Nordic and Baltic countries, which have plentiful forests. The increase in production of biomass in the future will create competition among the agriculture and forestry sectors for land, investment, research funding, etc. [36]. 


\section{Discussion}

\subsection{Trade between Local and Global as Well as Centralized and Decentralized Production}

Biomass is a unique renewable energy. Due to the fact that, as a direct combustible replacement to fossil fuels, it can be used in dispatchable centralized power stations. However, the major shortcoming of biomass is its lack of availability [86]. Growing international trade has led to improvements in biomass transport and storage over the past decade, with a rise in global biodiesel production, as it is considered to remain the main liquid renewable fuel, with several airlines beginning to operate commercial flights using biofuels. Limited, but growing, quantities of gaseous biofuels are fueling trains, buses, and other vehicles, particularly in Europe.

As biomass production in Europe will not be able to meet demand, industrialists have relied on imports of cheap biomass from other regions, primarily from Asia (65\% of total EU consumption) $[86,87]$. On the grounds of the increased demand for biomass, developing countries will face foreign companies that will want to acquire land within them. Within the political bioeconomy debate over whether it should be planned on a regional or global scale, industrialized countries claim the technological leadership in the production of biofuels. For industrialized countries, other countries are biomass suppliers, and are also markets in which to place bio-products and procure developed technologies [31,88].

When it comes to biorefineries, it is important to determine whether small-scale or large-scale facilities are needed and whether centralized or decentralized solutions should be pursued $[13,89]$.

When considering the bioeconomy, experiences from the past have shown that regional planning has led to negative environmental and social consequences. Developing countries that traditionally supply sugar-rich biomass have witnessed increased social injustice toward farmers on their own lands and the delayed development of human capital [89-92]. For that reason, many politicians and researchers point to the necessity to establish globally applicable sustainability certification procedures for biomass production to ensure global bioeconomy development with ecological, economic, and social benefits for all parties involved.

\subsection{The Centralized versus Decentralized Biorefineries}

In order to improve biofuel yields from biomass, modern and large biorefineries are necessary, which also imposes the need for large investments and loans $[47,65]$.

Consequently, the available literature in the field of design and the optimization of biomass supply chains focuses mainly on an economic point of view and emphasizes the investment and operational costs. It is often assumed that regional or industrial integration reduces the cost of biorefineries [51,93]. A number of previous studies $[5,22,36]$ show that the integration of biorefineries with other industries is possible, such as the use of excess heat from some processes and byproducts that can be integrated into traditional forest industries, as well as planning bio refineries in terms of logistics due to the industries huge experience with operating with a large-scale biomass. The prevalent attitude is that biorefineries, as a typical example of the bioeconomy, should be planned as largescale facilities characterized by huge throughputs via maximal investments into high-tech technologies in order to achieve the maximum use of biomass in the most sustainable way. Centralized plants could possibly be economically justified at certain sites only with the aim to maintain the transportation costs within realistic limits, such as large ports in regions like Russia, Finland, or Sweden. The Finnish strategy attempts for an in-between approach and promotes the idea that the local and global levels should be interrelated [1]. Some authors $[7,78]$ point out that a global-level development can only impede trade between innovation clusters, such as industrial biotechnology in Germany or the palm oil industry in Malaysia.

As an alternative to large-scale technologies, decentralized, smaller, highly specialized biorefineries tailored to the particular regional biomass supply and that produce subproducts of biofuels are also advocated, which requires lower transportation costs to the 
larger plants [94]. If raw materials are processed locally, the added value stays in the region, transport costs are as low as possible, and new workplaces are opened in rural areas; however, there is a limitation to the investment in continuously developing sustainable technologies. In any case, the stochastic nature of the dimension caused by seasonal effects should also be taken into account, instead of using deterministic variables for modeling and optimization $[86,95]$. Thus, decentralized supply chain configurations are proposed to improve economic performance indicators by the reduction of transportation costs in supply chains in areas with an advanced forestry sector and numerous, large biorefineries. With dispersed biomass availability, however, the distributed supply chains can turn competitive, which raises questions about sustainable supply where biorefineries are far away due to $\mathrm{CO}_{2}$ emissions [6].

Nevertheless, for lower production scenarios, slight difference in the supply chain costs for the centralized and decentralized supply chains exist [66,96]. It means that the cost advantage for centralized or decentralized configurations are closely and heavily dependent on the location and technology applied. Changes in transportation have a lesser impact on the supply chain costs, as compared to the biomass price. An increase or decrease in the transportation cost certainly will favor either the decentralized or centralized supply chain configuration to be applied [21].

A fall in biomass price certainly has a significant impact on the total system cost, but it is not evident how the biomass price decrease would influence the biomass usage by the system, particularly in situations when fossil fuel price decreases. The use of biofuels for transport, especially ethanol from the fermentation of carbohydrate crops, to substitute gasoline and vegetable oils instead of diesel fuel is desirable. However, it requires very large areas of land in order to provide an economically feasible contribution to the reduction of fossil fuel emissions and also has the potential to put further pressure on natural forests and grasslands $[65,93]$.

The cascading approach, such as the use of food waste and fermentation products for the second generation of biofuels, has disadvantages such as the decline in technical quality of recycled products, a lack of economic incentives for the collection of waste products. In addition, while there are cheap imported raw materials from abroad, there remains an inadequate infrastructure for the collection of waste repairing products and for their second-hand use $[49,97]$. As such, the initial circular economy and cascade concept, which prioritizes the collection of bio waste towards biofuel production without considering the additional $\mathrm{CO}_{2}$ footprint due to the collection and transport of waste or its decay of quality, is no longer valid $[98,99]$.

\subsection{Empirical Validation}

In addition, after deep theoretical research by a semi-systematic review methodology, a questionnaire containing possible conclusions was conducted. The questionnaire was shared with sustainability expert groups to be filled out on a voluntary basis. It has been filled in by 51 participants originating from 21 countries. Table 1 shows the demographic statistics of participants. 
Table 1. Participant's data.

\begin{tabular}{|c|c|c|c|}
\hline \multicolumn{2}{|c|}{ Sex } & \multicolumn{2}{|c|}{ Region } \\
\hline Male & $49 \%$ & Urban & $76.5 \%$ \\
\hline Female & $51 \%$ & Rural & $23.5 \%$ \\
\hline \multicolumn{2}{|c|}{ Age } & \multicolumn{2}{|c|}{ Academic degree } \\
\hline $18-25$ & $5.9 \%$ & \multirow{8}{*}{$\begin{array}{c}\text { Bachelor's or } \\
\text { equivalent } \\
\text { Master's or } \\
\text { equivalent } \\
\text { Doctoral or } \\
\text { equivalent }\end{array}$} & \\
\hline $26-30$ & $3.9 \%$ & & \\
\hline $31-35$ & $15.7 \%$ & & $4 \%$ \\
\hline $36-40$ & $9.8 \%$ & & $21.5 \%$ \\
\hline $41-45$ & $25.5 \%$ & & $74.5 \%$ \\
\hline $46-50$ & $15.7 \%$ & & \\
\hline $51-55$ & $7.8 \%$ & & \\
\hline $56-60$ & $3.9 \%$ & & \\
\hline $61-65$ & $7.8 \%$ & & \\
\hline $65+$ & $3.9 \%$ & & \\
\hline
\end{tabular}

The questionnaire had 15 different statements, and for all of them participants had to answer how strongly they agree using the Likert scale from 1 to 5 where 1 means "strongly disagree" and 5 means "strongly agree". Descriptive statistics have been done, and as is shown in Table 2, the mean values of almost all the answers are higher than 4 . The only statement that has a mean value lower than 4 is the statement about criticality of transportation, where the participants showed high levels of disagreement, which indicates that they recognized the issue of transportation. The values obtained for the answers empirically validate the conclusions drawn on the basis of the semi-systematic review.

Table 2. Descriptive statistics of collected data.

\begin{tabular}{|c|c|c|c|}
\hline & Question & $\begin{array}{l}\text { Mean } \\
\text { Value }\end{array}$ & $\begin{array}{l}\text { Standard } \\
\text { Deviation }\end{array}$ \\
\hline Q1 & $\begin{array}{l}\text { The balance between food and biomass uses of available land needs to be defined, while also } \\
\text { incorporating the protection of natural spaces in each country. }\end{array}$ & 4.67 & 0.589 \\
\hline Q2 & $\begin{array}{l}\text { The consolidated megatrend is to migrate from rural communities to cities, but today's processes of } \\
\text { biomass require a considerable amount of workforce in forests and arable lands. }\end{array}$ & 4.27 & 0.874 \\
\hline Q3 & COVID-19 pandemic will affect the aspects of globalization. & 4.32 & 1.095 \\
\hline Q4 & $\begin{array}{l}\text { Most countries are evolving from industrialization to a knowledge economy, so the professional education } \\
\text { for blue collar (or now green collar) workers needs to be properly implemented. }\end{array}$ & 4.49 & 0.674 \\
\hline Q5 & $\begin{array}{l}\text { After the crises of } 2008 \text { and COVID-19, some countries cannot finance more debt, so new infrastructure } \\
\text { projects must be privately funded. In this new scenario, the decision between centralizing or } \\
\text { decentralizing could even be taken solely by the business interest of a given company or fund. }\end{array}$ & 4.08 & 1.036 \\
\hline Q6 & $\begin{array}{l}\text { The decision for the centralized or decentralized process of biomass must take more elements into } \\
\text { consideration and not only the short-term cost. }\end{array}$ & 4.63 & 0.631 \\
\hline Q7 & $\begin{array}{l}\text { Mainly replacing crude oil with biomass might be correct using traditional economic criteria but may lead } \\
\text { to a misuse of natural resources and loss of the possibility to implement the learning points from the } \\
\text { decades of intensive use of crude oil. }\end{array}$ & 4.37 & 0.824 \\
\hline Q8 & Transport does not become more critical, not only because of the cost but also because of emissions. & 2.78 & 1.487 \\
\hline Q9 & $\begin{array}{l}\text { All new solutions will compete with stabilized infrastructures for the generation and distribution of crude } \\
\text { oil, gas, and electricity. }\end{array}$ & 4.35 & 0.820 \\
\hline Q10 & $\begin{array}{l}\text { Some of the traditional indicators are too much focused on short-term return on investment. } \\
\text { Renewable sources of biomass like a forest have not a closed period of use theoretically they are "eternal }\end{array}$ & 4.55 & 0.673 \\
\hline Q11 & $\begin{array}{l}\text { Renewable sources of biomass, like a forest, have not a closed period of use; theoretically, they are "eternal } \\
\text { by definition". We have no real tool to calculate the return on investment for a forest, as the forest will not } \\
\text { have a real expiration date. }\end{array}$ & 4.04 & 1.232 \\
\hline Q12 & $\begin{array}{l}\mathrm{CO}_{2} \text { emissions, water use, land use and some others are now being consolidated within a Life Cycle } \\
\text { Analysis, so this could be a way to compare different scenarios. }\end{array}$ & 4.37 & 0.774 \\
\hline Q13 & $\begin{array}{l}\text { Societal impact will vary considerably depending on the final scenario chosen, so this must be included in } \\
\text { the decision-making process. }\end{array}$ & 4.51 & 0.703 \\
\hline Q14 & The real dimension of globalization will be affected by the COVID-19 pandemic. & 4.18 & 1.090 \\
\hline Q15 & $\begin{array}{l}\text { A de-centralized solution and the vertical integration within each country could be a strategy to minimize } \\
\text { the impact of potential similar situations. }\end{array}$ & 4.05 & 0.899 \\
\hline
\end{tabular}




\section{Conclusions}

During the last few years, the prompt and sizable growth of renewable energy, along with the reduction in terms of the share of coal in energy production, leads to a more sustainable enhancement in carbon intensity in the power sector, such that the impact of the increased energy demand on carbon emissions has been partially offset. However, the offset is still only partial; regardless of the rapid rise in renewable energy, the speed of growth for energy demand still resulted in total carbon emissions from the electricity sector that have been amplified significantly in the last three years. As the analysis of the existing discourse in this review has shown, various considerations of the relationship between sustainability and the bioeconomy should be considered. In accordance with the greater part of the research, the bioeconomy will only add to a more sustainable future if certain, very important, requirements are fulfilled. A novel framework should comprise principles and criteria for a sustainable bioeconomy, and involve ecological, social, and economic aspects as an input for regulation, science, and broad society together, with a balance between all influential factors and objectives. The discussion on this essential topic is still in its early phase, and debate will last for years and has to be fortified in a sense to reach an internationally agreed set of criteria, including the trade of biomass between different regions of the world, land purchase, and the social wellbeing in those regions. Worldwide population growth, habits towards calorie-rich diets, and a rising request for biogenic raw materials require greater agricultural efficiency. The alternative of extending the cultivated regions is, for the most part, viewed as barely attainable without imperiling the remaining natural environments and the ecosystem services that they give. It is expected that the accessibility of fertile soil will shrivel due to worldwide environmental changes. The commonly acknowledged rule of "food first" gives priority to worldwide food security and that the food supply is adequate, nutritious, healthy, and safe for the world's growing population, even far above the required quantities, and this is placed ahead of all other ways to use biomass.

However, reliable facts about presently available quantities of biogenic raw materials, their spatial distribution, and their availability is lacking, and it is not possible to evaluate the level to which fossil fuels can be substituted by biogenic raw materials. To increase yields while improving environmental indicators, there are two diverse, sustainable paths: a high-tech strategy as an intensive approach to centralized agriculture and an agrienvironmental strategy as a transition to sustainable knowledge-based agriculture where local farmers play important roles. Keeping in mind the diversity among European farming systems, both proposed paths seem promising. Depending on the contextual factors, the energetic use of biomass should be limited to exceptions, such as the decentralized heat and electricity supply in sparsely populated rural areas or in the form of biofuels for specific purposes such as shipping and air transportation, while there are no viable alternatives for solar and wind energy.

Looking at European waste hierarchy, it is evident that combustion should only be considered as an option for the very end of the life cycle of biogenic products, and holistic and integrated life cycle assessment methodology should be applied to bioeconomy systems [100]. Thus far, other renewable energy roles within political bioeconomy strategies are not considered enough.

The degree to which consumers are incorporated in the concept differs together with their consumption patterns. There are consumption patterns which lead to environmentally conscious and responsible, reduction-aimed behavior, as critical levers for reducing the demand for biomass and lessening the pressure on land. The current path strongly relies on technology, which causes a narrow understanding by other disciplines, predominantly the social sciences, which results in numerous, unsolved, complex issues. As such, in the transition route, it is necessary to broaden technology-guided routes to the social field, especially when forming diversity strategies. It will certainly present novel challenges. For instance, biofuel products are defined as biofuels and not food in order to enable interregional trade and define the difference between food crops and biofuel crops. However, 
since an internationally agreed set of criteria for a sustainable bioeconomy does not yet exist, it should be emphasized that such criteria and restrictions have a significant impact on the potential of biomass that will be sustainably produced in the future. The EU criteria are related to the potential of biofuels to contribute to greenhouse gas reduction and the avoidance of direct land use changes, which is unavoidable due to the trends of massive urbanization and land abandonment, such as people moving to more developed countries or from agricultural areas to cities. The further inclusion of even stricter criteria would significantly reduce the available biomass potential.

Finally, the following points have to be mentioned:

1. The need for a consistent regulatory frame; There are numerous countries with applicable legislation and defined strategies about the bioeconomy, but they are not always consistent with other national laws and strategies on related issues.

1.1. The balance between food and biomass uses of available land needs to be defined, while also incorporating the protection of natural spaces in each country.

1.2. The consolidated megatrend is to migrate from rural communities to cities, but today's processes of biomass require a considerable workforce to be present in forests and arable lands.

1.3. Most countries are evolving from industrialization to a knowledge economy. The workforce needed in the biomass process requires traditional agricultural, forest, and transport skills. The limited creation of highly educated positions would be concentrated in the biorefining process. This is quite similar to the skills required today for crude oil, so the professional education for blue collar (or now green collar) workers needs to be properly implemented.

1.4. Funding of the infrastructure.

On large projects for gas or electricity, and even for crude oil, the main investor has been the government of a country. These utilities are a public service, so funding from taxpayers makes sense. The new situation, even more critical after the crises of 2008 and COVID-19, is that some countries cannot finance more debt, so new infrastructure projects must be privately funded. In this new scenario, the decision between centralizing or decentralizing could be taken solely by the business interest of a given company or fund.

2. The decision for the centralized or decentralized process of biomass must take more elements into consideration and not only the short-term cost.

2.1. Replacing crude oil with mainly biomass might be correct using traditional economic criteria, but may also lead to a misuse of natural resources and a loss of the possibility to implement the learning points from the decades of intensive use of crude oil.

2.2. To approach the generation of energy to the consumption point is even more important when we deal with substances with less specific energy. Transport becomes more critical, not only because of the cost, but also because of emissions.

2.3. All new solutions will compete with stabilized infrastructures for the generation and distribution of crude oil, gas, and electricity. Huge pipes communicating between different continents for the supply of gas or the big investments already deployed for windmills, will clearly limit the opportunities to implement the best possible solution.

3. Specific energy is key, but it is not the only criteria for the final selection of the solution.

3.1. Some traditional indicators are too focused on the short-term return on an investment. Renewable sources of biomass, such as a forest, do not have a closed period of use; theoretically, they are "eternal by definition". We have no real tool to calculate the return on an investment for a forest, as the forest will not have a real expiration date. 
3.2. $\mathrm{CO}_{2}$ emissions, water use, land use, and some other environmental issues are now being consolidated within a Life Cycle Analysis, so this could be a way to compare different scenarios.

3.3. Societal impact will vary considerably depending on the final scenario chosen, so this must be included in the decision-making process. The concept of societal impact also needs to be revised after the COVID-19 pandemic. The closing of the borders, as well as the difficulties for the harvest, storage, and transport of crops have created a new awareness for the need to take these issues into consideration.

3.4. The real dimension of globalization could also be affected by the COVID-19 pandemic.

A decentralized solution and the vertical integration within each country could be a strategy to minimize the impact of potential similar situations. Cooperation between countries might become more difficult or easier. During the COVID-19 crisis, we have observed an almost global coordination with almost all countries acting in equivalent ways to reduce the impact of the pandemic on the population. In addition, the health criteria have overruled the economic priority that was in place until this crisis occurred. It is too early to say if such global cooperation will be an exception or will remain.

4. Impact on the potential scenarios on the evolution of global democracy.

4.1. Replacing crude oil with biomass could lead to a similar situation with some countries producing most natural resources, others processing and refining them, and others consuming most of them. History shows us that the wealth generated by natural resources did not always improve the living conditions of citizens. Moreover, democracy is not the most predominant political system in countries that produce crude oil. The decision on how to evolve bioenergy can have a critical role in the evolution of political systems. This, combined with the new scenario after COVID-19 where individual freedom has been reduced for the common good, can lead to a significant change in the way that countries are governed.

4.2. The political impact might be even more difficult to assess, but it looks as though it is not a neutral element in this discussion. The same political system used to generate the legislation to move to a bioeconomy can also create a primary ally or enemy.

Elements for future research are the following:

A Definition of evaluation criteria for "eternal" investments, not only economical but also environmental (like the Life Cycle Analysis), social (such as the education level needed for the bioeconomic workforce), and governance (ESG).

B Definition of potential scenarios, such as only replacing crude oil with biomass or integrating vertically, decentralizing energy production, or approaching the generation to the consumption.

C Based on the experience on the influence of crude oil on the political systems of the production countries, we should try to assess the potential effect of each scenario on the country's political system and on its geopolitical relations.

The limitation of this paper, surely, is the number of participants who participated in the questionnaire survey. Future lines of the research should be focused on motivating more participants willing to fill in the questionnaire, as well as a deeper analysis of the questionnaire, such as a factor and reliability analysis. In addition, a systematic review and meta-analysis are recommended due to the importance of the topic examined. 


\begin{abstract}
Author Contributions: K.D.-M. contributed substantially to the conception and design of the article. M.P. contributed substantially to the interpretation of the relevant literature and to the writing of the manuscript. E.B. drafted the article. M.I. critically revised the article for important intellectual content. V.S.B. supervised and considered experts on the topic. All authors have read and agreed to the published version of the manuscript.
\end{abstract}

Funding: This research received no external funding.

Institutional Review Board Statement: The questionnaire protocol was approved by the Ethical Committee of the University of Belgrade-Faculty of Mechanical Engineering.

Informed Consent Statement: Informed consent was obtained from all subjects involved in the study.

Data Availability Statement: The data that support the findings of this study are available from the corresponding author upon reasonable request.

Acknowledgments: The survey is partially supported by MESTD grants from the SAF€RA project RESMOD and contract 451-03-68/2020-14/200105 (subproject TR 35017).

Conflicts of Interest: The authors declare no conflict of interest.

\title{
References
}

1. Beddington, J. Food, Energy, Water and the climate: A perfect storm of global events? In Chief Scientific Adviser to HM Government; DTI: London, UK, 2009; pp. 1-9.

2. Conti, J.; Holtberg, P.; Diefenderfer, J.; LaRose, A.; Turnure, J.T.; Westfall, L. International Energy Outlook 2016 with Projections to 2040; USDOE Energy Information Administration (EIA), Office of Energy Analysis: Washington, DC, USA, 2016.

3. Conticini, E.; Frediani, B.; Caro, D. Can Atmospheric Pollution Be Considered a Co-Factor in Extremely High Level of SARS-CoV-2 Lethality in Northern Italy? Environ. Pollut. 2020, 261, 114465. [CrossRef] [PubMed]

4. Budischak, C.; Sewell, D.; Thomson, H.; Mach, L.; Veron, D.E.; Kempton, W. Cost-Minimized Combinations of Wind Power, Solar Power and Electrochemical Storage, Powering the Grid up to 99.9\% of the Time. J. Power Sources 2013, 225, 60-74. [CrossRef]

5. Stewart, R.; Niero, M. Circular Economy in Corporate Sustainability Strategies: A Review of Corporate Sustainability Reports in the Fast-Moving Consumer Goods Sector. Bus. Strategy Environ. 2018, 27, 1005-1022. [CrossRef]

6. Huang, Z.; Yu, H.; Peng, Z.; Feng, Y. Planning Community Energy System in the Industry 4.0 Era: Achievements, Challenges and a Potential Solution. Renew. Sustain. Energy Rev. 2017, 78, 710-721. [CrossRef]

7. Overbeek, G.; De Bakker, E.; Beekman, V.; Kiresiewa, Z.; Delbrück, S.; Ribeiro, B.; Stoyanov, M.; Vale, M. Review of Bioeconomy Strategies at Regional and National Levels; The European Union: Brussels, Belgium, 2020.

8. Ingrao, C.; Bacenetti, J.; Bezama, A.; Blok, V.; Goglio, P.; Koukios, E.G.; Lindner, M.; Nemecek, T.; Siracusa, V.; Zabaniotou, A.; et al. The Potential Roles of Bio-Economy in the Transition to Equitable, Sustainable, Post Fossil-Carbon Societies: Findings from This Virtual Special Issue. J. Clean. Prod. 2018, 204, 471-488. [CrossRef]

9. Priefer, C.; Jörissen, J.; Frör, O. Pathways to Shape the Bioeconomy. Resources 2017, 6, 10. [CrossRef]

10. Muscat, A.; De Olde, E.M.; Ripoll-Bosch, R.; Van Zanten, H.H.E.; Metze, T.A.P.; Termeer, C.J.A.M.; van Ittersum, M.K.; De Boer, I.J.M. Principles, Drivers and Opportunities of a Circular Bioeconomy. Nat. Food 2021, 2, 561-566. [CrossRef]

11. Mayumi, K.; Gowdy, J.M. (Eds.) Bioeconomics and Sustainability: Essays in Honor of Nicholas Georgescu-Roegen; Edward Elgar Pub.: Cheltenham, UK; Northampton, MA, USA, 1999; ISBN 978-1-85898-667-8.

12. McCormick, K.; Kautto, N. The Bioeconomy in Europe: An Overview. Sustainability 2013, 5, 2589-2608. [CrossRef]

13. Rosenberg, N. Technological Change in the Machine Tool Industry, 1840-1910. J. Econ. Hist. 1963, 23, 414-443. [CrossRef]

14. Hoffmann, S.; Thompson Klein, J.; Pohl, C. Linking Transdisciplinary Research Projects with Science and Practice at Large: Introducing Insights from Knowledge Utilization. Environ. Sci. Policy 2019, 102, 36-42. [CrossRef]

15. Abad-Segura, E.; Batlles-delaFuente, A.; González-Zamar, M.-D.; Belmonte-Ureña, L.J. Implications for Sustainability of the Joint Application of Bioeconomy and Circular Economy: A Worldwide Trend Study. Sustainability 2021, 13, 7182. [CrossRef]

16. Bonviu, F. The European Economy: From a Linear to a Circular Economy. Romanian J. Eur. Aff. 2014, 14, 78.

17. Atz, U.; Van Holt, T.; Douglas, E.; Whelan, T. The Return on Sustainability Investment (ROSI): Monetizing Financial Benefits of Sustainability Actions in Companies. In Sustainable Consumption and Production, Volume II: Circular Economy and Beyond; Bali Swain, R., Sweet, S., Eds.; Springer International Publishing: Berlin/Heidelberg, Germany, 2021; pp. 303-354. ISBN 978-3-030-55285-5.

18. Coccia, M. Two Mechanisms for Accelerated Diffusion of COVID-19 Outbreaks in Regions with High Intensity of Population and Polluting Industrialization: The Air Pollution-to-Human and Human-to-Human Transmission Dynamics. MedRxiv 2020, $48 B, 1-45$.

19. Di Marco, M.; Baker, M.L.; Daszak, P.; Barro, P.D.; Eskew, E.A.; Godde, C.M.; Harwood, T.D.; Herrero, M.; Hoskins, A.J.; Johnson, E.; et al. Opinion: Sustainable Development Must Account for Pandemic Risk. Proc. Natl. Acad. Sci. USA 2020, 117, $3888-3892$. [CrossRef] [PubMed]

20. Shangguan, Z.; Wang, M.Y.; Sun, W. What Caused the Outbreak of COVID-19 in China: From the Perspective of Crisis Management. Int. J. Environ. Res. Public Health 2020, 17, 3279. [CrossRef] 
21. Fargione, J.; Hill, J.; Tilman, D.; Polasky, S.; Hawthorne, P. Land Clearing and the Biofuel Carbon Debt. Science 2008, 319, 1235-1238. [CrossRef]

22. BP Energy Economics. BP Statistical Review of World Energy Report; British Petroleum: London, UK, 2019.

23. Vo, X.V.; Zaman, K. Relationship between Energy Demand, Financial Development, and Carbon Emissions in a Panel of 101 Countries: "Go the Extra Mile" for Sustainable Development. Environ. Sci. Pollut. Res. 2020, 27, 23356-23363. [CrossRef]

24. Peters, G.P.; Andrew, R.M.; Canadell, J.G.; Friedlingstein, P.; Jackson, R.B.; Korsbakken, J.I.; Le Quéré, C.; Peregon, A. Carbon Dioxide Emissions Continue to Grow amidst Slowly Emerging Climate Policies. Nat. Clim. Chang. 2020, 10, 3-6. [CrossRef]

25. Rae, C.; Bradley, F. Energy Autonomy in Sustainable Communities-A Review of Key Issues. Renew. Sustain. Energy Rev. 2012, 16, 6497-6506. [CrossRef]

26. IEA. Global Energy Review 2019. Available online: https:/ / www.iea.org/reports/global-energy-review-2019 (accessed on 22 March 2021).

27. Pawar, S.S.; Van Niel, E.W.J. Thermophilic Biohydrogen Production: How Far Are We? Appl. Microbiol. Biotechnol. 2013, 97, 7999-8009. [CrossRef]

28. Sikora, A. European Green Deal-Legal and Financial Challenges of the Climate Change. ERA Forum 2021, 21, 681-697. [CrossRef]

29. Dimić-Mišić, K.; Barceló, E.; Spasojević-Brkić, V.; Gane, P. Identifying the Challenges of Implementing a European Bioeconomy Based on Forest Resources: Reality Demands Circularity. FME Trans. 2019, 47, 60-69. [CrossRef]

30. Bezama, A. Let Us Discuss How Cascading Can Help Implement the Circular Economy and the Bio-Economy Strategies. Waste Manag. Res. 2016, 34, 593-594. [CrossRef]

31. Dahiya, S.; Kumar, A.N.; Shanthi Sravan, J.; Chatterjee, S.; Sarkar, O.; Mohan, S.V. Food Waste Biorefinery: Sustainable Strategy for Circular Bioeconomy. Bioresour. Technol. 2018, 248, 2-12. [CrossRef]

32. Dimitriou, I.; Goldingay, H.; Bridgwater, A.V. Techno-Economic and Uncertainty Analysis of Biomass to Liquid (BTL) Systems for Transport Fuel Production. Renew. Sustain. Energy Rev. 2018, 88, 160-175. [CrossRef]

33. Chum, H.L.; Overend, R.P. Biomass and Renewable Fuels. Fuel Processing Technol. 2001, 9, 187-195. [CrossRef]

34. Ioannou, I.; Serafeim, G. Corporate Sustainability: A Strategy? Social Science Research Network: Rochester, NY, USA, 2019.

35. Mathews, J.A. Biofuels: What a Biopact between North and South Could Achieve. Energy Policy 2007, 35, 3550-3570. [CrossRef]

36. Smáradóttir, S.E.; Magnúsdóttir, L.; Smárason, B.Ö.; Pórðarson, G.; Johannessen, B.; Stefánsdóttir, E.K.; Jacobsen, B.; Laksá, U.; Solberg, S.Ø.; Vang, J.; et al. Future Opportunities for Bioeconomy in the West Nordic Countries. Matis. Accessed Jan. 2014, 6, 2015.

37. De Man, R.; Friege, H. Circular Economy: European Policy on Shaky Ground. Waste Manag. Res. 2016, 34, 93-95. [CrossRef]

38. Santibañez-Aguilar, J.E.; Morales-Rodriguez, R.; González-Campos, J.B.; Ponce-Ortega, J.M. Stochastic Design of Biorefinery Supply Chains Considering Economic and Environmental Objectives. J. Clean. Prod. 2016, 136, 224-245. [CrossRef]

39. Meyer, R. Bioeconomy Strategies: Contexts, Visions, Guiding Implementation Principles and Resulting Debates. Sustainability 2017, 9, 1031. [CrossRef]

40. D'Amato, D.; Droste, N.; Allen, B.; Kettunen, M.; Lähtinen, K.; Korhonen, J.; Leskinen, P.; Matthies, B.D.; Toppinen, A. Green, Circular, Bio Economy: A Comparative Analysis of Sustainability Avenues. J. Clean. Prod. 2017, 168, 716-734. [CrossRef]

41. Staffas, L.; Gustavsson, M.; McCormick, K. Strategies and Policies for the Bioeconomy and Bio-Based Economy: An Analysis of Official National Approaches. Sustainability 2013, 5, 2751-2769. [CrossRef]

42. BIOCOM AG BioStep. Overview of Political Bioeconomic Strategies. 2018. Available online: http://www.bio-step.eu/ background/bioeconomy-strategies.html (accessed on 22 March 2021).

43. World Bank. Global GDP for 2019. Available online: https://data.worldbank.org/indicator/NY.GDP.MKTP.CD?view=chart (accessed on 13 February 2021).

44. Jiang, D.; Zhuang, D.; Fu, J.; Huang, Y.; Wen, K. Bioenergy Potential from Crop Residues in China: Availability and Distribution. Renew. Sustain. Energy Rev. 2012, 16, 1377-1382. [CrossRef]

45. Carrington, G.; Stephenson, J. The Politics of Energy Scenarios: Are International Energy Agency and Other Conservative Projections Hampering the Renewable Energy Transition? Energy Res. Soc. Sci. 2018, 46, 103-113. [CrossRef]

46. Jacquet, N.; Haubruge, E.; Richel, A. Production of Biofuels and Biomolecules in the Framework of Circular Economy: A Regional Case Study. Waste Manag. Res. 2015, 33, 1121-1126. [CrossRef]

47. Pérez, A.T.E.; Camargo, M.; Narváez Rincón, P.C.; Alfaro Marchant, M. Key Challenges and Requirements for Sustainable and Industrialized Biorefinery Supply Chain Design and Management: A Bibliographic Analysis. Renew. Sustain. Energy Rev. 2017, 69, 350-359. [CrossRef]

48. Zetterholm, J.; Pettersson, K.; Leduc, S.; Mesfun, S.; Lundgren, J.; Wetterlund, E. Resource Efficiency or Economy of Scale: Biorefinery Supply Chain Configurations for Co-Gasification of Black Liquor and Pyrolysis Liquids. Appl. Energy 2018, 230, 912-924. [CrossRef]

49. Karmee, S.K.; Lin, C.S.K. Lipids from Food Waste as Feedstock for Biodiesel Production: Case Hong Kong. Lipid Technol. 2014, 26, 206-209. [CrossRef]

50. Porter, M.; Siggelkow, N. Contextuality Within Activity Systems and Sustainability of Competitive Advantage. AMP 2008, 22, 34-56. [CrossRef]

51. Finkbeiner, M. (Ed.) Towards Life Cycle Sustainability Management, 1st ed.; Springer: Berlin/Heidelberg, Germany, 2011; ISBN 978-94-007-1899-9. 
52. Mathiesen, B.V.; Lund, H.; Connolly, D. Limiting Biomass Consumption for Heating in 100\% Renewable Energy Systems. Energy 2012, 48, 160-168. [CrossRef]

53. Lund, H. Renewable Energy Strategies for Sustainable Development. Energy 2007, 32, 912-919. [CrossRef]

54. Nigam, P.S.; Singh, A. Production of Liquid Biofuels from Renewable Resources. Prog. Energy Combust. Sci. 2011, 37, 52-68. [CrossRef]

55. Hepbasli, A. A Key Review on Exergetic Analysis and Assessment of Renewable Energy Resources for a Sustainable Future. Renew. Sustain. Energy Rev. 2008, 12, 593-661. [CrossRef]

56. Miller, D.; Welch, R. Food System Strategies for Preventing Micronutrient Malnutrition-ScienceDirect. Food Policy 2013, 42, 115-128. [CrossRef]

57. Mathiesen, B.V.; Connolly, D.; Lund, H.; Nielsen, M.P.; Schaltz, E.; Wenzel, H.; Bentsen, N.S.; Felby, C.; Kaspersen, P.; Ridjan, I.; et al. CEESA 100\% Renewable Energy Transport Scenarios towards 2050: Technical Background Report Part 2; Department of Development and Planning, Aalborg University: Aalborg, Denmark, 2014.

58. Thrän, D.; Bezama, A. The Knowledge-Based Bioeconomy and Its Impact in Our Working Field. Waste Manag. Res. 2017, 35, 689-690. [CrossRef]

59. Navia, R.; Mohanty, A.K. Resources and Waste Management in a Bio-Based Economy. Waste Manag. Res. 2012, 30, 215-216. [CrossRef] [PubMed]

60. Dornburg, V.; Faaij, A.P.C. Efficiency and Economy of Wood-Ÿred Biomass Energy Systems in Relation to Scale Regarding Heat and Power Generation Using Combustion and Gasiÿcation Technologies. Biomass Bioenergy 2001, 18, 91-108. [CrossRef]

61. Berndes, G.; Hoogwijk, M.; Van Den Broek, R. The Contribution of Biomass in the Future Global Energy Supply: A Review of 17 Studies. Biomass Bioenergy 2003, 25, 1-28. [CrossRef]

62. Dornburg, V.; Faaij, A.; Verweij, P.; Langeveld, H.; Van De Ven, G.; Wester, F.; Van Keulen, H.; Van Diepen, K.; Meeusen, M.; Banse, M.; et al. Global Biomass Potentials and Their Links to Food, Water, Biodiversity, Energy Demand and Economy; Netherlands Environmental Assessment Agency: Hague, The Netherlands, 2008.

63. Nagar, H. Sustainable Raw Material Selection for Pulp and Paper Using SAW Multiple Criteria Decision Making Design. IPPTA J. 2015, 27, 67-76.

64. Vermerris, W. Miscanthus: Genetic Resources and Breeding Potential to Enhance Bioenergy Production. In Genetic Improvement of Bioenergy Crops; Vermerris, W., Ed.; Springer New York: New York, NY, USA, 2008; pp. 295-308. ISBN 978-0-387-70804-1.

65. Mills, E. The Insurance and Risk Management Industries: New Players in the Delivery of Energy-Efficient and Renewable Energy Products and Services. Energy Policy 2003, 31, 1257-1272. [CrossRef]

66. Righelato, R.; Spracklen, D.V. Carbon Mitigation by Biofuels or by Saving and Restoring Forests? Science 2007, 317, 902. [CrossRef]

67. Scheer, H. The Solar Economy: Renewable Energy for a Sustainable Global Future; Routledge: London, UK, 2004; ISBN 978-1-84977-392-8.

68. Capellán-Pérez, I.; De Castro, C.; Arto, I. Assessing Vulnerabilities and Limits in the Transition to Renewable Energies: Land Requirements under 100\% Solar Energy Scenarios. Renew. Sustain. Energy Rev. 2017, 77, 760-782. [CrossRef]

69. Arenas-Arenas, F.J.; Castro-García, S.; Blanco-Roldan, G.L.; Salguero, A.; Hervalejo, A.; Merino, C.; Gil-Ribes, J.A. Field Evaluation of two canopy shake systems for mechanical harvesting on citrus orchards in andalusia (Spain). Acta Hortic. 2015, 1065, 1853-1859. [CrossRef]

70. Hart, C.; Hayes, D.; Jacobs, K.; Schulz, L.; Crespi, J. The Impact of COVID-19 on Iowa's Corn, Soybean, Ethanol, Pork, and Beef Sectors; CARD Policy Briefs: Ames, IA, USA, 2020; pp. 1-15.

71. Cheval, S.; Mihai Adamescu, C.; Georgiadis, T.; Herrnegger, M.; Piticar, A.; Legates, D.R. Observed and Potential Impacts of the COVID-19 Pandemic on the Environment. Int. J. Environ. Res. Public Health 2020, 17, 4140. [CrossRef] [PubMed]

72. Khurshid, A.; Khan, K. How COVID-19 Shock Will Drive the Economy and Climate? A Data-Driven Approach to Model and Forecast. Environ. Sci. Pollut. Res. 2021, 28, 2948-2958. [CrossRef] [PubMed]

73. Maliszewska, M.; Mattoo, A.; Van Der Mensbrugghe, D. The Potential Impact of COVID-19 on GDP and Trade: A Preliminary Assessment; Social Science Research Network: Rochester, NY, USA, 2020.

74. Talavari, R.; Hosseini, S.; Moradi, G. Low-Cost Biodiesel Production Using Waste Oil and Catalyst. Waste Manag. Res. 2021, 39, 250-259. [CrossRef] [PubMed]

75. Graham, B.S.; Sullivan, N.J. Emerging Viral Diseases from a Vaccinology Perspective: Preparing for the next Pandemic. Nat. Immunol. 2018, 19, 20-28. [CrossRef] [PubMed]

76. Staub, J. International Energy Outlook; Center for Strategic and International Studie: Washington, DC, USA, 2017.

77. Agrawal, R.; Singh, N.R. Solar Energy to Biofuels. Annu. Rev. Chem. Biomol. Eng. 2010, 1, 343-364. [CrossRef]

78. Bhatti, U.; Sulaiman, N. Impact of Sustainability Practices on Share Performance with Mediation of Green Innovation: A Conceptual Paper. Int. J. Psychosoc. Rehabil. 2020, 24, 1826-1836. [CrossRef]

79. Zhang, J.; Yang, J.; Zhang, H.; Zhang, Z.; Zhang, Y. Research Status and Future Development of Biomass Liquid Fuels. BioResources 2021, 16, 4523-4543. [CrossRef]

80. Loftus, P.J.; Cohen, A.M.; Long, J.C.S.; Jenkins, J.D. A Critical Review of Global Decarbonization Scenarios: What Do They Tell Us about Feasibility? WIREs Clim. Change 2015, 6, 93-112. [CrossRef]

81. Loos, J.; Abson, D.J.; Chappell, M.J.; Hanspach, J.; Mikulcak, F.; Tichit, M.; Fischer, J. Putting Meaning Back into “Sustainable Intensification". Front. Ecol. Environ. 2014, 12, 356-361. [CrossRef] 
82. Garnett, T.; Appleby, M.C.; Balmford, A.; Bateman, I.J.; Benton, T.G.; Bloomer, P.; Burlingame, B.; Dawkins, M.; Dolan, L.; Fraser, D.; et al. Sustainable Intensification in Agriculture: Premises and Policies. Science 2013, 341, 33-34. [CrossRef]

83. Thirukkumaran, C.M.; Parkinson, D. Microbial Respiration, Biomass, Metabolic Quotient and Litter Decomposition in a Lodgepole Pine Forest floor Amended with Nitrogen and Phosphorous Fertilizers. Soil Biol. 2000, 8, 59-66. [CrossRef]

84. Hamelinck, C.N.; Faaij, A.P.C. Outlook for Advanced Biofuels. Energy Policy 2006, 34, 3268-3283. [CrossRef]

85. Houghton, R.A. Carbon Emissions and the Drivers of Deforestation and Forest Degradation in the Tropics. Curr. Opin. Environ. Sustain. 2012, 4, 597-603. [CrossRef]

86. Chen, Q.; Liu, T. Biogas System in Rural China: Upgrading from Decentralized to Centralized? Renew. Sustain. Energy Rev. 2017, 78, 933-944. [CrossRef]

87. Sikkema, R. Use of forest based biomass for bioenergy in EU-28. Res. Rural. Dev. 2014, 2, 7-13.

88. Carley, M.; Christie, I. Managing Sustainable Development, 2nd ed.; Routledge: London, UK, 2017; ISBN 978-1-315-09152-5.

89. McKenna, R. The Double-Edged Sword of Decentralized Energy Autonomy. Energy Policy 2018, 113, 747-750. [CrossRef]

90. James, P. Urban Sustainability in Theory and Practice: Circles of Sustainability; Routledge: Oxfordshire, UK, 2014; ISBN 978-1-317-65836-8.

91. Morsing, M.; Schultz, M. Corporate Social Responsibility Communication: Stakeholder Information, Response and Involvement Strategies. Bus. Ethics A Eur. Rev. 2006, 15, 323-338. [CrossRef]

92. Wilson, D.C.; Velis, C.A. Cities and Waste: Current and Emerging Issues. Waste Manag. Res. 2014, 32, 797-799. [CrossRef]

93. Freeman, R.E.; Wicks, A.C.; Parmar, B. Stakeholder Theory and "The Corporate Objective Revisited". Organ. Sci. 2004, 15, 364-369. [CrossRef]

94. Sawatdeenarunat, C.; Nam, H.; Adhikari, S.; Sung, S.; Khanal, S.K. Decentralized Biorefinery for Lignocellulosic Biomass: Integrating Anaerobic Digestion with Thermochemical Conversion. Bioresour. Technol. 2018, 250, 140-147. [CrossRef]

95. Bali Swain, R.; Sweet, S. Sustainable Consumption and Production, Volume II, 1st ed.; Springer Nature: Berlin/Heidelberg, Germany, 2021; ISBN 978-3-030-55284-8.

96. Piccinno, F.; Hischier, R.; Saba, A.; Mitrano, D.; Seeger, S.; Som, C. Multi-Perspective Application Selection: A Method to Identify Sustainable Applications for New Materials Using the Example of Cellulose Nanofiber Reinforced Composites. J. Clean. Prod. 2016, 112, 1199-1210. [CrossRef]

97. Vaish, B.; Sharma, B.; Srivastava, V.; Singh, P.; Ibrahim, M.H.; Singh, R.P. Energy Recovery Potential and Environmental Impact of Gasification for Municipal Solid Waste. Biofuels 2019, 10, 87-100. [CrossRef]

98. Santibañez-Aguilar, J.E.; González-Campos, J.B.; Ponce-Ortega, J.M.; Serna-González, M.; El-Halwagi, M.M. Optimal Planning and Site Selection for Distributed Multiproduct Biorefineries Involving Economic, Environmental and Social Objectives. J. Clean. Prod. 2014, 65, 270-294. [CrossRef]

99. Cristóbal, J.; Caldeira, C.; Corrado, S.; Sala, S. Techno-Economic and Profitability Analysis of Food Waste Biorefineries at European Level. Bioresour. Technol. 2018, 259, 244-252. [CrossRef]

100. Zeug, W.; Bezama, A.; Thrän, D. A Framework for Implementing Holistic and Integrated Life Cycle Sustainability Assessment of Regional Bioeconomy. Int. J. Life Cycle Assess. 2021, 26, 1998-2023. [CrossRef] 